Asian J Agric \& Biol. 2021(3).

\title{
Comparative incidence of maize stem borers on GM and non-GM maize under two smallholder cropping systems in the Eastern Cape province of South Africa
}

\author{
Daniel Ashie Kotey ${ }^{1,2 *}$, Yoseph Assefa ${ }^{2,3}$, Johnnie Van den Berg 4 \\ ${ }^{1}$ Council for Scientific and Industrial Research-Plant Genetic Resources Research Institute, P.O. Box 7, Bunso, Ghana \\ ${ }^{2}$ Department of Zoology and Entomology, University of Fort Hare, Alice, 5700, South Africa \\ ${ }^{3}$ Department of Crop Production, Faculty of Agriculture, University of Swaziland, Luyengo, M205, Swaziland \\ ${ }^{4}$ Unit for Environmental Sciences and Management, North-West University, Potchefstroom, 2520, South Africa
}

Received:

December 11, 2020

Accepted:

March 13, 2021

Online First:

April 02, 2021

Published:

July 07, 2021

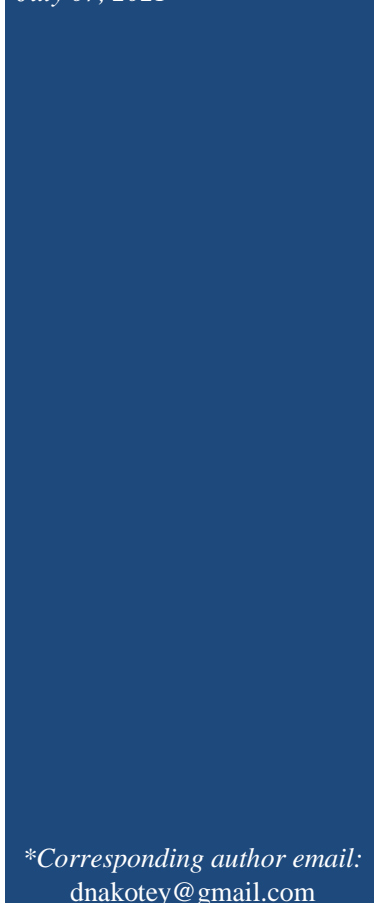

dnakotey@gmail.com

\begin{abstract}
The assessment of the comparative performance of technologies, especially, those identified as alternatives, under smallholder farmers' conditions, can enhance the sustainable dissemination and adoption of improved agricultural technologies. To this end, the performance of a genetically modified (GM) stacked-trait herbicide and insect resistant Bacillus thuringiensis (Bt) maize hybrid was compared to a GM herbicide tolerant hybrid, a non-GM hybrid and an open pollinated variety (OPV). The trials were conducted in three localities under natural stem borer infestation in irrigated and nonirrigated (dryland) fields. No stem borer infestation was observed on Bt maize plants from the seedling to the flowering stages in all fields at all trial sites. Stem borer infestation was higher under irrigation compared to dryland conditions. The stem borer complex on non-Bt maize plants under irrigation was dominated by Chilo partellus whilst only Busseola fusca larvae were recorded under dryland conditions. The yield of the Bt maize variety under irrigation was significantly higher than that of the OPV but not different $(P>0.05)$ from that of the non-Bt hybrids. No significant $(\mathrm{P}>0.05)$ difference in yield was observed between $\mathrm{Bt}$ and non-Bt maize varieties under dryland conditions. The results highlight the need to base dissemination and adoption decisions of relatively expensive agricultural technologies such as GM maize on the results of context specific field trials.
\end{abstract}

Keywords: GM maize, Open pollinated maize, Smallholder, Stem borer

\section{How to cite this:}

Kotey DA, Assefa Y and Van den Berg J, 2021. Comparative incidence of maize stem borers on GM and non-GM maize under two smallholder cropping systems in the Eastern Cape province of South Africa. Asian J. Agric. Biol. 2021(3): 202010550. DOI: https://doi.org/10.35495/ajab.2020.10.550

This is an Open Access article distributed under the terms of the Creative Commons Attribution 3.0 License. (https://creativecommons.org/licenses/by/3.0), which permits unrestricted use, distribution, and reproduction in any medium, provided the original work is properly cited.

\section{Introduction}

Maize is one of the most important crops in subSaharan Africa. Historically, yields of the crop in
Africa have been low compared to other maize producing regions. Attempts at increasing yields to meet the food demands of an increasing population have been constrained by abiotic and biotic stresses 


\section{A. Kotey et al.}

(Tandzi and Mutengwa, 2020). Notable amongst these is infestation by stem borer pests such as the African maize stem borer, Busseola fusca (Fuller) (Lepidoptera: Noctuidae) and the spotted stem borer, Chilo partellus (Swinhoe) (Lepidoptera: Crambidae) (Kfir et al., 2002; Van den Berg et al., 2015). Depending on agro-ecological zone, pest population density, plant growth stage at infestation and cultivar type, infestation by stem borers can result in yield losses of $88 \%$ (Kfir et al., 2002). Chilo partellus and B. fusca are the main pests of maize in South Africa occurring either singly or in mixed populations (Van den Berg et al., 1991a; Ntiri et al., 2016). Generally, smallholder farmers are aware of the negative impact of $C$. partellus and B. fusca infestation on their maize crop and yield (De Groote et al., 2003). Owing to the lack of resources (Smith, 1997), very few smallholder farmers apply insecticides onto their maize crop. Furthermore, the efficacy of insecticides may be limited by the lack of proper timing of application and difficulty to reach the target pests inside the maize whorl (Eizaguirre et al., 2002; Slabbert and Van den Berg, 2009). In view of these challenges, the availability of genetically modified (GM) insect resistant maize varieties in South Africa was seen as a potentially important development that could provide smallholder farmers with practical and economical ways to minimize maize yield losses due to stem borer pests (Hellmich et al., 2008; Brookes and Barfoot, 2014). In South Africa, Bt maize provides effective control of $C$. partellus and Sesamia calamistis (Hampson) (Lepidoptera: Noctuidae) but partial to very good control of B. fusca (Van den Berg and Van Wyk, 2007; Kotey et al., 2017; Strydom et al., 2019). Despite repeated efforts by both Government and nongovernmental organizations to get smallholder farmers in South Africa to use Bt maize, the adoption of the technology by smallholders has been minimal. This is due to the use of top-down technology dissemination approaches, lack of adequate extension and advisory support, relatively high input costs and non-compatibility of Bt maize technology stewardship requirements with smallholder maize production practices (Jacobson and Myhr, 2012; Fischer et al., 2015; Kotey et al., 2016).

In contrast to large monoculture maize production, smallholder maize production is undertaken under varying agro-ecologies and conditions (Arias et al., 2013; Van den Berg and Campagne, 2014). In South Africa, smallholder maize production takes place under dryland conditions (Hamann and Tuinder, 2012) in outfields (farm lands situated outside villages or residential sites ranging in size from 1 to 5 hectares), home gardens (small plots of land between 0.1 and 0.5 hectares that are adjacent to residential dwellings) (Bryndum et al., 2007) or in open rangelands using simple outdated technologies (Pienaar, 2013) including recycled seeds of open pollinated varieties of maize (Gouse et al., 2005; Fischer and Hajdu, 2015). In most instances, the main maize crop is intercropped with pulses, pumpkins, groundnuts, onions, carrots and sweet potatoes to mitigate the risk of crop failure (Bryndum et al., 2007; Jacobson and Myhr, 2012). Ploughing and planting operations in home gardens are generally undertaken using draught animals (Manona, 2005). The use of inputs such as fertilizer and mechanized equipment only occurs when outfields are cultivated as part of subsidized governmental and non-governmental initiatives (Kotey et al., 2017). Due to the diversity of production conditions and methods, the output and benefits of agricultural technologies used by smallholders may vary across locations and seasons (Heatherly et al., 2002; Kambhampati et al., 2006; Gouse et al., 2005; 2006). Thus, the evaluation of the performance of new maize varieties like $\mathrm{Bt}$ maize relative to varieties commonly cultivated by smallholders under local farming conditions and pest infestation levels may provide information that can be used in prioritizing and disseminating the most cost-effective technologies for improvement of smallholder maize production and livelihoods (De Groote, 2002; De Grassi, 2003). This study was conducted to assess the comparative incidence and damage of stem borers on $\mathrm{Bt}$ and non-Bt maize in smallholder farms under dryland and irrigation conditions in the Eastern Cape province of South Africa.

\section{Material and Methods}

\section{Selection of trial locations}

Two dryland maize production areas with high pest pressure were identified by means of field surveys in 13 different localities (10 fields per locality) in the Eastern Cape province of South Africa during the 2014/2015 cropping season. The selected locations were Bhala $\left(\mathrm{S} 30.94832^{\circ} \mathrm{E} 29.54863^{\circ}\right)$ (mean incidence of stem borer infested plants per field $=35.3 \%$ ) and Nxanxadi (S31.13137 E29.63938 ${ }^{\circ}$ (mean incidence of infested plants $=36.2 \%)$. Another locality, the Zanyokwe irrigation scheme (S32.75783 
E27.05600 ${ }^{\circ}$, was included as a stem borer hot-spot based on farmers' reports of high incidence of these pests.

\section{Maize varieties}

Four maize varieties were evaluated in this study. These were: PAN 5R-993BR (a 'stacked' trait hybrid with Bt insect resistance and herbicide tolerance), PAN 5Q-649R (a herbicide tolerant hybrid with similar maturity to that of the stacked-trait hybrid), PAN12 (non-GM hybrid) and Okavango an Open Pollinated Variety (OPV).

\section{Description of trial locations and experimental design}

The study under irrigation conditions was conducted at the Zanyokwe irrigation Scheme in Keiskammahoek, in the Amathole District Municipality of the Eastern Cape Province. The irrigation scheme has a total irrigated land area of about 439 ha with approximately 61 farmers, each with an average land holding of 4.2 ha (Fanadzo et al., 2010). The area receives a mean annual rainfall of 580 $\mathrm{mm}$ which is supplemented with sprinkler irrigation. The soils in the area are characterized by Arcadia (Vertisol) and Shortlands soil forms (Chromic Luvisol) (SCWG, 1991). Bt maize was first cultivated at the Scheme as part of the Massive Food Production Program (MFPP) managed by the Eastern Cape Department of Agriculture (ECDA). At the time of the study, farmers at the scheme cultivated Bt maize as part of the Cropping Program of the Department of Rural Development and Agrarian Reform (DRDAR). Under the Cropping Program, government subsidized inputs and services are supplied to farmers at the irrigation scheme.

The dryland trials were conducted at Nxanxadi and Bhala. These two areas fall under the Flagstaff service centre of DRDAR in the Ingquza Hill Local Municipality of the OR Tambo District Municipality. Flagstaff normally receives about $749 \mathrm{~mm}$ of rainfall per year. Most of the rainfall occurs between September and May. The underlying geology of the area is composed of hard quartzite rock of the Natal group sandstones which gives rise to sandy, highly leached and relatively shallow soils which are not suitable for intensive agriculture (Nicolson, 1993).

Each of the selected farms used for the experiment had previously been cultivated to maize. The experimental design was randomized complete block replicated three times at each location. Each replicate consisted of four $50 \times 10 \mathrm{~m}$ plots. Planting was done in late October, 2015. All fields in one area were planted on the same day using a tractor drawn planter. Inter- and intra-row distances of $0.75 \mathrm{~m}$ and $0.33 \mathrm{~m}$ was used to achieve a plant population of 40,000 seeds per hectare as is the normal practice in the area. Plots of each replicate consisted of 12 rows of 120-130 plants. The four inner rows were used for data collection while the four outer rows on both ends of the inner rows were maintained as guard rows. The plant stand per row was determined at the six-leaf stage. Two rows of PAN 5Q-649R were planted around the perimeter of each field to prevent intrusion and tampering with the trials. All maize production practices recommended as part of the Cropping Program were observed. The action threshold for chemical control of stem borers in maize is when $10 \%$ of plants (mixed infestations of B. fusca and $C$. partellus) in a field show visible symptoms of whorl damage (Van den Berg et al., 2015). Under the Cropping Program however, farmers apply insecticides preventatively when maize plants are between four and seven weeks old. Weed control is also undertaken at the same crop growth stage.

The incidence of stem borer infested plants was determined at the seedling (emergence to V3 stage), vegetative (6 weeks after emergence (WAE)), flowering and post-flowering growth stages. During each assessment, a total of 100 maize plants in the four middle rows of each plot were inspected for symptoms of borer damage to whorl leaves, entry and exit holes in the stems and ears of plants. The number of plants with symptoms of borer damage in each plot was expressed as a percentage of the total number of plants per plot. During each damage assessment, 10 infested plants from the outer rows in each plot were dissected to identify the stem borer species present in fields. The number of ears per plant was determined at harvest. Thirty maize plants from the two middle rows of each plot (variety) at each location were randomly selected and tagged 20-24 WAE. The area from which ears were harvested in each plot was approximately $10 \mathrm{~m}^{2}$. The number of ears per tagged plant was determined after which ears were harvested. Each harvested ear was assessed for the presence of stem borer damage after which the extent of damage (tunnel length) on each ear was recorded. The number of damaged internodes per plant was determined by dissecting the stems of all the 30 randomly selected plants from which ears were harvested. The harvested ears from each plot were individually weighed using a Sartorius balance (maximum weight $=5000 \mathrm{~g}$ ) and recorded. The 


\section{A. Kotey et al.}

weighed ears were threshed and used to calculate yield per plot, which was then expressed in tons/ha. Grain moisture content at harvest was determined with an intelligent grain moisture meter and used to calculate and compare the grain moisture-standardized yield of the maize varieties as follows (Badu-Apraku et al., 2012):

$$
\text { Yield }(\text { at } 12.5 \% \text { m.c })=\text { Grain yield }\left(\frac{\text { tons }}{h a}\right) \times \frac{(100-\text { actual grain moisture } \%)}{87.5}
$$

\section{Statistical analysis}

Data on pre- and post-flowering stem borer incidence and grain yield for each trial site were analyzed separately by way of univariate analysis of variance (ANOVA), using SPSS (version 24) statistics software (IBM Corporation, USA). Multiple comparisons to identify differences among significant treatment means was done using Tukey's HSD test. Correlation analysis was performed separately using Microsoft Excel (Microsoft Office, version 10).

\section{Results}

\section{Stem borer infestation levels}

Only B. fusca larvae were recovered from non-Bt maize plants under dryland conditions. With respect to maize plants under irrigation conditions, C. partellus constituted $74.9 \%, 75.0 \%$ and $95.4 \%$ of the larvae recovered from maize plants at the vegetative, flowering and post flowering growth stages respectively. No stem borer damage was observed on any of the Bt maize plants from the seedling to the flowering stages in all fields at all trial sites (Table 1). On non-Bt maize plants, damage symptoms were first observed three weeks after emergence (WAE) and the incidence increased steadily up to the post-flowering stage. The incidence of damaged plants was higher under irrigation (Zanyokwe) than under dryland conditions (Nxanxadi and Bhala) (Table 1). Generally, the incidence of damaged plants at all plant growth stages was higher on the OPV than on the two non-Bt hybrids, PAN 5Q-649R and PAN 12.

The incidences of stem borer damaged plants at the seedling stage did not differ significantly between $\mathrm{Bt}$ and non-Bt maize plots at any of the locations $(P>$ 0.05). Differences in the incidence of damaged plants between the non-Bt maize varieties were not significant at the vegetative and flowering stages under irrigation conditions. During the post-flowering stage however, significantly $(P<0.001)$ fewer plants of PAN 5Q-649R (47.4\%) were infested as compared to OPV plants $(83.0 \%)$.

At Nxanxadi, the incidence of damaged non-Bt maize plants ranged from $0.2 \%$ (PAN 5Q-649R) at the seedling stage to $29.3 \%$ (OPV) at the post-flowering stage. The incidence of damaged plants of PAN 12 $(15.1 \%)$ at the flowering stage was significantly $(P=0.000)$ lower than the incidence of damaged plants of the OPV (18.8\%; Table 1). At Bhala, the incidence of damaged plants ranged between $1.0 \%$ (PAN 5Q$649 \mathrm{R})$ and $32.2 \%(\mathrm{OPV})$ at the seedling and post flowering stages respectively (Table 1).

Table-1. Comparative incidence of stem borer damaged plants on $B t$ and non-Bt maize fields under irrigation and dryland conditions in the Eastern Cape, South Africa

\begin{tabular}{|c|c|c|c|c|}
\hline \multirow{2}{*}{ Variety and site } & \multicolumn{4}{|c|}{ Mean incidence of borer damage plants (\%) } \\
\hline & Seedling & Vegetative & Flowering & Post-flowering \\
\hline \multicolumn{5}{|c|}{ Zanyokwe irrigation scheme } \\
\hline \begin{tabular}{|l|} 
OPV \\
PAN 12 \\
PAN 5Q-649R \\
PAN 5R- \\
993BR \\
\end{tabular} & $\begin{array}{l}1.0 \\
0.8 \\
0.0 \\
0.0\end{array}$ & $\begin{array}{l}31.1 \mathrm{a}^{*} \\
29.0^{\mathrm{a}} \\
23.0^{\mathrm{a}} \\
0.0^{\mathrm{b}}\end{array}$ & $\begin{array}{c}39.1^{\mathrm{a} *} \\
36.1^{\mathrm{a}} \\
29.4^{\mathrm{a}} \\
0.0^{\mathrm{b}}\end{array}$ & $\begin{array}{c}83.0^{\mathrm{a} *} \\
67.8^{\mathrm{ab}} \\
47.4^{\mathrm{b}} \\
0.0^{\mathrm{c}}\end{array}$ \\
\hline $\begin{array}{l}F \text {-value } \\
P \text {-value }\end{array}$ & $\begin{array}{c}1.80 \\
0.168 \\
\end{array}$ & $\begin{array}{l}30.70 \\
0.000\end{array}$ & $\begin{array}{l}36.33 \\
0.000\end{array}$ & $\begin{array}{l}64.18 \\
0.000\end{array}$ \\
\hline \multicolumn{5}{|l|}{ Nxanxadi } \\
\hline \begin{tabular}{|l|} 
OPV \\
PAN 12 \\
PAN 5Q-649R \\
PAN 5R- \\
993BR \\
\end{tabular} & $\begin{array}{l}0.7 \\
1.1 \\
0.2 \\
0.0\end{array}$ & $\begin{array}{c}14.2^{\mathrm{a} *} \\
13.2^{\mathrm{a}} \\
13.0^{\mathrm{a}} \\
0.0^{\mathrm{b}}\end{array}$ & $\begin{array}{c}18.8^{\mathrm{a} *} \\
15.1^{\mathrm{b}} \\
15.8^{\mathrm{ab}} \\
0.0^{\mathrm{c}}\end{array}$ & $\begin{array}{c}29.3^{\mathrm{a} *} \\
27.3^{\mathrm{a}} \\
26.3^{\mathrm{a}} \\
0.0^{\mathrm{b}}\end{array}$ \\
\hline $\begin{array}{l}F \text {-value } \\
P \text {-value }\end{array}$ & $\begin{array}{c}4.84 \\
0.007 \\
\end{array}$ & $\begin{array}{c}38.44 \\
0.000\end{array}$ & $\begin{array}{l}94.75 \\
0.000 \\
\end{array}$ & $\begin{array}{c}161.51 \\
0.000 \\
\end{array}$ \\
\hline \multicolumn{5}{|l|}{ Bhala } \\
\hline $\begin{array}{l}\text { OPV } \\
\text { PAN 12 } \\
\text { PAN 5Q-649R } \\
\text { PAN 5R- } \\
\text { 993BR } \\
\end{array}$ & $\begin{array}{l}1.7 \\
1.4 \\
1.0 \\
0.0\end{array}$ & $\begin{array}{c}15.0^{\mathrm{a} *} \\
14.2^{\mathrm{a}} \\
14.7^{\mathrm{a}} \\
0.0^{\mathrm{b}}\end{array}$ & $\begin{array}{c}18.4^{\mathrm{a} *} \\
17.4^{\mathrm{a}} \\
17.3^{\mathrm{a}} \\
0.0^{\mathrm{b}}\end{array}$ & $\begin{array}{c}32.8^{\mathrm{a} *} \\
30.4^{\mathrm{a}} \\
30.2^{\mathrm{a}} \\
0.0^{\mathrm{b}}\end{array}$ \\
\hline $\begin{array}{l}F \text {-value } \\
P \text {-value }\end{array}$ & $\begin{array}{l}2.06 \\
0.13\end{array}$ & $\begin{array}{c}168.63 \\
0.000\end{array}$ & $\begin{array}{c}145.31 \\
0.000 \\
\end{array}$ & $\begin{array}{c}192.26 \\
0.000\end{array}$ \\
\hline
\end{tabular}

*Means within the same column followed by different letter(s) are significantly different at the 0.05 level.

Under irrigation, the mean number of damaged internodes per plant of PAN 5Q-649R (0.6 per stem) was not significantly $(P>0.05)$ different from that of the Bt maize variety ( 0.0 per stem). A significantly ( $P$ $<0.001)$ higher number of internodes were damaged in stems of PAN 12 (3.4) than the other varieties under irrigation (Table 2). At both dryland trial sites, there were no significant differences between the mean number of damaged internodes per plant of PAN 5Q- 


\section{A. Kotey et al.}

649R and the Bt maize variety. At Bhala, the mean number of damaged internodes per plant of PAN 12 (0.1) was not significantly different from that of $\mathrm{Bt}$ maize plants $(0.0 \%)$ (Table 2$)$.

Under irrigation conditions, the mean length of tunnels bored by stem borer larvae in stems of PAN 5Q-649R $(0.6 \mathrm{~cm})$ were significantly shorter than those in stems of the OPV $(21.5 \mathrm{~cm})$ and PAN $12(33.2 \mathrm{~cm})$. Mean tunnel lengths per stem at both Nxanxadi and Bhala did not differ significantly (Table 2 ).

Table-2. Comparative damage caused by stem borer larvae to $B t$ and non-Bt maize plants at different locations.

\begin{tabular}{|l|c|c|c|}
\hline \multirow{2}{*}{ Variety } & \multicolumn{3}{c|}{ Location of trial } \\
\cline { 2 - 4 } & Zanyokwe Nxanxadi & Bhala \\
\hline Mean number of internodes damaged \\
\hline OPV & $1.0^{\mathrm{b} *}$ & $0.5^{\mathrm{a} *}$ & $0.2^{\mathrm{a} *}$ \\
PAN 12 & $3.4^{\mathrm{a}}$ & $0.6^{\mathrm{a}}$ & $0.1^{\mathrm{ab}}$ \\
PAN 5Q-649R & $0.6^{\mathrm{bc}}$ & $0.1^{\mathrm{b}}$ & $0.1^{\mathrm{ab}}$ \\
PAN 5R-993BR & $0.0^{\mathrm{c}}$ & $0.0^{\mathrm{b}}$ & $0.0^{\mathrm{b}}$ \\
\hline$F$-value & 51.72 & 9.64 & 2.93 \\
$P$-value & $<0.001$ & $<0.001$ & 0.034 \\
\hline Mean length of stem tunnel (cm) & \\
\hline OPV & $21.5^{\mathrm{a} *}$ & 17.3 & 10.8 \\
PAN 12 & $33.2^{\mathrm{a}}$ & 12.5 & 14.7 \\
PAN 5Q-649R & $13.6^{\mathrm{b}}$ & 16.2 & 12.3 \\
\hline$F$-value & 5.52 & 0.60 & 0.49 \\
$P$-value & $<0.005$ & $>0.05$ & $>0.05$ \\
\hline
\end{tabular}

*Means within the same column followed by different letter(s) are significantly different at the 0.05 level.

The mean number of ears harvested from PAN 5R993BR under irrigation was 1.7 per plant, which was significantly $(P<0.001)$ higher than that of any of the non-Bt maize varieties cultivated under irrigation conditions. There were no significant $(P>0.05)$ differences between the mean number of ears per plant among any of the varieties cultivated under dryland conditions at both Nxanxadi and Bhala. The mean number of ears per plant (1.1) was significantly $(P<$ $0.001)$ lower for PAN 12 than the other varieties at Nxanxadi.

No stem borer damage was observed on ears harvested from Bt maize plants under irrigation. The incidence of stem borer damaged ears on non-Bt hybrids and the OPV under irrigation conditions ranged from 16.7 (PAN 5Q-649R) to 30.0\% (PAN 12) (Table 3). No significant differences $(P>0.05)$ were observed between the percentage damaged ears of Bt maize and non-Bt maize under dryland conditions. At Nxanxadi, none of the harvested ears of PAN 5Q-649R and PAN 5R-993BR showed borer damage and only $6.7 \%$ (OPV) and 10\% (PAN 12) of harvested ears were infested at this location. At Bhala, $7.8 \%$ of $\mathrm{Bt}$ maize ears showed signs of borer damage. The highest percentage of damaged ears at this location (21.1\%) was observed in the OPV plots (Table 3).

Table-3. Incidence of damaged ears per plant and degree of damage caused by stem borer larvae to maize ears at harvest

\begin{tabular}{|c|c|c|c|}
\hline \multirow{2}{*}{ Variety } & \multicolumn{3}{|c|}{ Location of trial } \\
\hline & Zanyokv & Nxanxadi & Bhala \\
\hline \multicolumn{4}{|c|}{ Mean percentage of ears exhibiting borer damage } \\
\hline OPV & 20.0 & 6.7 & 21.1 \\
\hline PAN 12 & 30.0 & 10.0 & 12.2 \\
\hline PAN 5Q-649R & 16.7 & - & 11.1 \\
\hline PAN 5R-993BR & - & - & 7.8 \\
\hline$F$-value & 1.89 & 1.93 & 1.38 \\
\hline$P$-value & $>0.05$ & $>0.05$ & $>0.05$ \\
\hline \multicolumn{4}{|c|}{ Mean length of tunnel on ear $(\mathrm{cm})$} \\
\hline OPV & $5.3^{\mathrm{ab} *}$ & 4.3 & 3.6 \\
\hline PAN 12 & $6.2^{\mathrm{a}}$ & 6.0 & 4.8 \\
\hline PAN 5Q-649R & $3.7^{\mathrm{b}}$ & - & 4.7 \\
\hline PAN 5R-993BR & - & - & 4.2 \\
\hline$F$-value & 3.64 & 2.82 & 1.36 \\
\hline$P$-value & 0.033 & $>0.05$ & $>0.05$ \\
\hline
\end{tabular}

*Means within the same column followed by different letter(s) are significantly different at the 0.05 level.

Damage to ears was characterized by tunnels and in most cases fungal infection was observed. The mean tunnel length ranged between 0.0 and $6.2 \mathrm{~cm}$ per ear with the lowest recorded for PAN 5Q-649R under irrigation. Differences in mean tunnel lengths on ears between varieties in both dryland trials were not significant $(P>0.05)$. Mean tunnel lengths in ears were $19.6 \%$ (PAN 5Q-649R), 30.5\% (OPV) and $31.0 \%$ (PAN 12) of the mean total lengths of ears of these varieties under irrigation. With respect to dryland conditions, it was $26.2 \%$ (OPV) and $34.1 \%$ (PAN 12) of the mean total length of ears harvested at Nxanxadi and 26.5\% (OPV), 29.2\% (PAN 5R993BR), 31.6\% (PAN 12) and 32.8\% (PAN 5Q-649R) of the mean total length of harvested ears at Bhala (Table 3).

\section{Effect of stem borer infestation on maize grain yield}

There was a significant $(P<0.05)$ negative correlation 


\section{A. Kotey et al.}

$(\mathrm{r}=-0.99)$ between stem tunnel length and grain yield obtained for PAN 12 plants cultivated under irrigation. For all other varieties, neither the number of damaged internodes per plant nor stem tunnel length correlated significantly $(P>0.05)$ with grain yield at any of the locations.

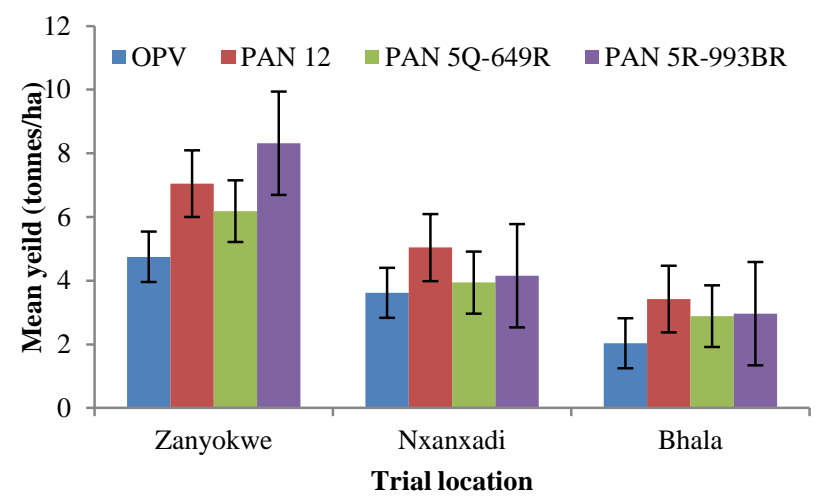

Figure-1. Yield of four maize varieties cultivated under irrigation and dryland conditions

The yield obtained under irrigation ranged from 8.32 tons/ha (PAN 5R-993BR) to 4.75 ton/ha (OPV). Whilst the yield obtained from the insect-resistant PAN 5R-993BR was significantly $(P<0.05)$ higher than that obtained from the OPV, it was not different from that obtained from PAN 12 or PAN 5Q-649R (Figure 1). Differences in yield obtained under dryland conditions at both Nxanxadi and Bhala did not differ significantly $(P>0.05)$. Yield obtained at Nxanxadi ranged from 3.62 ton/ha (OPV) to 5.04 ton/ha (PAN 12) while at Bhala it ranged from 2.04 ton/ha (OPV) to 3.42 ton/ha (PAN 12) (Figure 1).

\section{Discussion}

Results of the current study show that stem borer infestation was higher under irrigation compared to dryland conditions. The stem borer complex on nonBt maize plants under irrigation was dominated by Chilo partellus whilst only Busseola fusca larvae were recorded under dryland conditions. No stem borer infestation was observed on Bt maize plants from the seedling to the flowering stages in all fields at all trial sites. Comparatively, more maize plants under irrigation showed symptoms of stem borer damage than maize plants cultivated under dryland conditions. More OPV plants were infested than plants of the other two non-Bt varieties, PAN 12 and PAN 5Q-649R, at all plant growth stages and at all locations. The comparatively high incidence of stem borer damaged plants under irrigation conditions concurs with Van Rensburg (2007) who reported that stem borer moths have a preference for high humidity conditions such as those prevailing in irrigated fields. Therefore, more serious infestations may occur under conditions of high precipitation (Van Rensburg et al., 1987a). In a previous study at the Zanyokwe irrigation scheme, Fanadzo et al. (2009) reported that plants of Okavango (the OPV) suffered increased borer attack after the late vegetative stage of crop development. Compared to the other varieties used in this study, the OPV has a relatively longer maturity period. It has been reported that maize cultivars with long growing seasons are more susceptible to stem borer damage than cultivars with short growing season (Van Rensburg et al., 1988a). This may therefore explain the relatively high incidence of stem borer damage on the OPV in this study.

No stem borer infestation was observed on Bt-maize plants at any location prior to the grain filling stage. The only damage to Bt maize plants occurred at Bhala where $7.8 \%$ of ears showed signs of borer damage. This may be ascribed to the ability of B. fusca larvae to survive on less toxic tissues of $\mathrm{Bt}$ maize plants during the post-flowering stages of maize development (Van Rensburg, 2001). Visual estimation of the incidence of borer infested plants indicated that more than $10 \%$ of non-Bt maize plants at all locations were infested during the vegetative and post flowering stages. The majority of farmers indicated that they made once-off applications of insecticides during the mid-vegetative growth stage. The rationale for this was that the Cropping Program budget mostly accounts for only one mechanized application (herbicide and insecticide) using a tractor-mounted boom sprayer. Insecticide application was therefore undertaken at this time when it was also expected that weeds would have been sufficiently established and of optimum size to warrant chemical control. Following insecticide application at all trial sites, there was a marked reduction in the incidence of newly infested maize plants at the flowering stage at all locations.

The incidence of stem borer damaged plants increased over time in spite of the application of insecticides at the mid-vegetative stages. It has been reported that the onset of tasseling causes larval migration from the disappearing whorls of plants to the tassel and ears as well as to neighboring plants where secondary stem borer attack occurs over a relatively short period of time (Van Rensburg et al., 1988b; Erasmus et al., 


\section{A. Kotey et al.}

2016; Visser et al., 2020). The increased incidence of damaged plants over time observed in this study, suggests that migrating larvae were able to infest neighboring plants due to the short residual period of the insecticides applied (Van Rensburg and Van den Berg, 1992a) and the fact that applications often did not reach areas (Slabbert and Van den Berg, 2009) harboring stem borer larvae. Due to the migratory behavior of stem borer larvae, late or delayed insecticide application, particularly after the tasseling of maize plants has been suggested to provide some control of large larvae originating from infestations during the vegetative stages (Van den Berg, 1991; Van Rensburg and Van den Berg, 1992b). The Cropping Program's strategy of making once-off applications of insecticides at the early vegetative stage may therefore have to be revised or replaced by a threshold-based stem borer management approach. In South Africa, the accepted threshold for the initiation of chemical control actions against C. partellus is when $40 \%$ of plants exhibit whorl damage symptoms (Bate and Van Rensburg, 1992). With regard to mixed infestations of $C$. partellus and B. fusca, the accepted threshold is when $10 \%$ of maize plants exhibit whorl damage (Van Rensburg and Bate, 1987).

In this study, with the exception of stem tunnel length which showed significant negative correlation with grain yield in plants of PAN 12, there were no significant correlations between other stem borer damage parameters and grain yield in any of the other varieties. Studies conducted by Ebenebe et al. (2000) reported that yield losses in local OPVs and commercial hybrids in Lesotho were generally not proportionate to the incidence of stem borer damaged plants. Van den Berg and Van Rensburg (1991) however reported that similar stem borer infestation levels in maize plantings with different yield potential results in significantly different yield losses with highyielding varieties and plantings suffering a proportionately higher yield loss. The stem borer complex under irrigation was largely dominated by $C$. partellus. It has been reported to be less injurious to maize plants than B. fusca (Van den Berg et al., 1991a; 1991b). These factors may therefore explain the significant negative correlation between the degree of stem tunneling and grain yield of PAN 12 plants under irrigation conditions.

\section{Conclusion}

This study showed that Bt maize provides effective control of stem borers and increased yield under high input conditions. These advantages were however not achieved under conditions prevailing in smallholder systems in the Eastern Cape province of South Africa. Due to the technology fees associated with the use of GM maize seed and co-technologies, farmers may be burdened with upfront costs and debt, particularly in seasons with low pest and weed pressure and low amounts of rainfall. In view of these, evidence-based policy making, based on the evaluation of the value of available maize varieties and their profitability under pest and weed management systems and agronomic conditions prevailing in smallholder systems, should be a priority.

Disclaimer: The mention of any product in this manuscript does not constitute an endorsement.

Conflict of Interest: None.

Source of Funding: The Agricultural Research Council Collaboration Centre for Smallholder Development and the Govan Mbeki Research and Development Centre, University of Fort Hare, the National Research Foundation (Grant No. TP14082593855) of South Africa, are hereby acknowledged for their financial support.

\section{References}

Arias P, Hallam D, Krivonos E and Morrison J, 2013. Smallholder integration in changing food markets. Food and Agriculture Organization (FAO) of the United Nations, Rome, Italy.

Badu-Apraku B, Fakorede MAB, Menkir A and Sanogo D, 2012. Conduct and management of maize field trials. International Institute of Tropical Agriculture, Ibadan, Nigeria.

Bate R and Van Rensburg JBJ, 1992. Predictive estimation of maize yield loss caused by Chilo partellus (Swinhoe) (Lepidoptera: Pyralidae) in maize. S. Afr. J. Plant Soil. 9: 150-154.

Brookes $\mathrm{G}$ and Barfoot P, 2014. Economic impact of GM crops: the global income and production effects 1996-2012. GM Crops Food. 5: 65-75.

Bryndum S, Bøye C, Chongtham IR and Montagne J, 2007. Present and future potentials of agriculture in Pepela village, Eastern Cape Province, South Africa. Report of the Interdisciplinary project in land use and natural resource management. Faculty of Life Sciences, University of Copenhagen, Denmark.

De Grassi A, 2003. Genetically modified crops and 
sustainable poverty alleviation in Sub-Saharan Africa: An assessment of current evidence, Third World Network-Africa Publisher.

De Groote H, 2002. Maize yield losses from stem borers in Kenya. Insect Sci. Appl. 22: 89-96.

De Groote H, Overholt B, Okuro JO and Mugo S, 2003. Assessing the potential impact of Bt maize in Kenya using a GIS based model. XXVth Conference of the International Association of Agricultural Economics, 16-22 August 2003, Durban, South Africa.

Ebenebe AA, Van den Berg $\mathrm{J}$ and Van der Linde TC, 2000. Response of local maize varieties and commercial hybrids to natural infestation by Busseola fusca (Fuller) (Lepidoptera: Noctuidae) in Lesotho. S. Afr. J. Plant Soil. 17: 74-79.

Eizaguirre M, Sans A, López C and Albajes R, 2002. Effects of Mating Disruption against the Mediterranean Corn Borer, Sesamia nonagrioides, on the European corn borer Ostrinia nubilalis. Int. Org. Bio. Control West Palaearctic Reg. Sec. Bull. 25: 1-10.

Erasmus A, Marais J and Van Den Berg J, 2016. Movement and survival of Busseola fusca (Lepidoptera: Noctuidae) larvae within maize plantings with different ratios of non- $B t$ and $B t$ seed. Pest Manage. Sci. 72:2287-2294.

Fanadzo M, Chiduza C, Mnkeni PNS, van der Stoep I and Stevens J, 2010. Crop production management practices as a cause for low water productivity at Zanyokwe irrigation scheme. Water SA. 36: 27-36.

Fanadzo M, Chiduza C and Mnkeni PNS, 2009. Investigation of agronomic factors constraining productivity of grain maize (Zea mays L.) at Zanyokwe irrigation scheme, Eastern Cape, South Africa. J. Appl. Biosci. 17: 948 - 958.

Fischer K, Van den Berg J and Mutengwa C, 2015. Is $\mathrm{Bt}$ maize effective in improving South African smallholder agriculture? S. Afr. J. Sci. 111:1-2.

Fischer K and Hajdu F, 2015. Does raising maize yields lead to poverty reduction? A case study of the Massive Food Production Programme in South Africa. Land Use Policy 46: 304-313.

Gouse M, Pray CE, Kirsten J and Schimmelpfennig D, 2005. A GM subsistence crop in Africa: the case of Bt white maize in South Africa. Int. J. Biotech 7: 84-94.

Gouse M, Pray CE, Schimmelpfennig D and Kirsten J, 2006. Three seasons of subsistence insectresistant maize in South Africa: Have smallholders benefited? AgBioForum. 9: 15-22.

Hamann $M$ and Tuinder V, 2012. Introducing the Eastern Cape: A quick guide to its history, diversity and future challenges. Stockholm Resilience Centre (SRC), Stockholm Sweden.

Heatherly LG, Elmore CD and Spurlock SR, 2002. Weed management systems for conventional and glyphosate-resistant soybean with and without irrigation. Agron. J. 94:11925-11930.

Hellmich RL, Albajes R, Bergvinson D, Prasifka JR, Wang ZY and Weiss MJ, 2008. The present and future role of insect-resistant genetically modified maize in IPM, 119-158. In J. Romeis, A.M. Shelton and G.G. Kennedy (eds.), Integration of Insect-resistant Genetically Modified Crops Within IPM Programs. Springer Science + Business Media. Dordrecht, The Netherlands.

Jacobson K and Myhr AI, 2012. GM crops and smallholders: biosafety and local practice. J. Environ. Dev. 22: $104-124$.

Kambhampati U, Morse S, Bennett R and Ismael Y, 2006. Farm-level performance of genetically modified cotton: A frontier analysis of cotton production in Maharashtra. Outlook Agric. 35: 291-297.

Kfir R, Overholt WA, Khan ZR and Polaszek A, 2002. Biology and management of economically important Lepidopteran cereal stem borers in Africa. Annu. Rev. Entomol. 47:701-731.

Kotey DA, Obi A, Assefa Y, Erasmus A and Van den Berg J, 2017. Monitoring resistance to Bt maize in field populations of Busseola fusca (Fuller) (Lepidoptera: Noctuidae) from smallholder farms in the Eastern Cape Province of South Africa. Afr. Entomol. 25: 200-209.

Kotey DA, Assefa Y, Obi A and Van den Berg J, 2016. Disseminating genetically modified (GM) maize technology to smallholder farmers in the Eastern Cape Province of South Africa: extension personnel's awareness of stewardship Requirements and dissemination practices. S. Afr. J. Agric. Ext. 44: 59-74.

Kotey DA, Assefa Y and Van den Berg J, 2017. Enhancing smallholder farmers' awareness of GM maize technology, management practices and compliance to stewardship requirements in the Eastern Cape Province of South Africa: The role of public extension \& advisory services. S. Afr. J. Agric. Ext. 45: 49-63.

Manona SS, 2005. Smallholder agriculture as local economic development strategy in rural South 
Africa: Exploring prospects in Pondoland, Eastern Cape. M. Phil Thesis (Land \& Agrarian Studies), Programme for Land and Agrarian Studies, Faculty of Economic and Management Sciences, University Of Western Cape, South Africa.

Nicolson G, 1993. Transkei coastal development plan: Annexure 1. Description and analysis of the coast, a draft. Umtata, South Africa.

Ntiri ES, Calatayud PA, Van den Berg J, Schulthess F and Le Ru BP, 2016. Influence of temperature on intra- and interspecific resource utilisation within a community of lepidopteran maize stemborers. PLoS ONE 11: e0148735.

Pienaar PL, 2013. Typology of smallholder farming in South Africa's former Homelands: Towards an appropriate classification system. Master of Science in Agriculture Thesis, Faculty of AgriSciences, Stellenbosch University, South Africa. 122pp.

Slabbert O and Van den Berg J, 2009. The effect of the adjuvant, Break-Thru S240, on whorl penetration and efficacy of foliar insecticide applications against Chilo partellus. S. Afr. J. Plant Soil. 26: $254-258$.

Smith CM, 1997. An overview of the mechanisms and bases of insect resistance in maize. In J.A. Mihm (ed), Insect resistant maize: Recent Advances and Utilization; Proceedings of an International Symposium held at the International Maize and Wheat Improvement Centre (CIMMYT) 27 November-3 December, 1994. Mexico, D.F.: CIMMYT, Mexico.

(SCWG) Soil Classification Working Group, 1991. Soil Classification: A taxonomic system for South Africa. Memoirs on the agricultural natural resources of South Africa No. 15. Soil and Irrigation Research Institute, Department of Agricultural Development, Pretoria, South Africa.

Strydom E, Erasmus A, Du Plessis H and Van den Berg J, 2019. Resistance status of Busseola fusca populations to single- and stacked-gene Bt maize in South Africa. J. Econ. Entomol. 112: 305-316.

Tandzi NL and Mutengwa CS, 2020. Factors Affecting Yield of Crops, 1-16. In: Amanullah, (ed), Agronomy Climate Change and Food Security. Intech Open Limited, Princes Gate Court, London, SW7 2QJ, United Kingdom.

Van den Berg J, 1991. Unavoidable losses in insecticidal control of Chilo partellus (Swinhoe) (Lepidoptera: Pyralidae) in maize and grain sorghum. S. Afr. J. Plant Soil. 8:12-15.

Van den Berg $\mathbf{J}$ and Campagne P, 2014. Resistance of Busseola fusca to Cry $1 \mathrm{Ab} \mathrm{Bt}$ maize plants in South Africa and challenges to insect resistance management in Africa. 4: 36-48. In M. Soberón, M., Y. Gao and Bravo, A. (eds), Characterization and strategies for GM crops producing Bacillus thuringiensis toxins. CABI Biotechnology Series, CABI International, Wallingford, United Kingdom.

Van den Berg J, Erasmus A and Van Rooyen M, 2015. Maize. 88-118. In G.L. Prinsloo, and V.M. Uys (eds), Insects of Cultivated Plants and Natural Pastures in Southern Africa. Entomological Society of Southern Africa, Hatfield, South Africa.

Van den Berg $\mathbf{J}$ and Van Rensburg JBJ, 1991. Infestation and injury levels of stem borers in relation to yield potential of grain sorghum. S. Afr. J. Plant Soil. 8: 127-131.

Van den Berg J, Van Rensburg JBJ and Pringle KL, 1991a. Comparative injuriousness of Busseola fusca (Lepidoptera: Noctuidae) and Chilo partellus (Lepidoptera: Pyralidae) on grain sorghum. Bull. Entomol. Res. 82: 137-143.

Van den Berg J, Van Rensburg JBJ and Van der Westhuizen MC, 1991b. The effect of single and mixed populations of Busseola fusca (Lepidoptera: Noctuidae) and Chilo partellus (Swinhoe) (Lepidoptera: Pyralidae) on damage to grain sorghum. J. Entomol. Soc. South. Afr. 54: 231-242.

Van den Berg J and Van Wyk A, 2007. The effect of Bt maize on Sesamia calamistis (Lepidoptera: Noctuidae) in South Africa. Entomol. Exp. Appl. 122: 45-51.

Van Rensburg JBJ, 2001. Larval mortality and injury patterns of the African stalk borer, Busseola fusca (Fuller) on various plant parts of Bt-transgenic maize. S. Afr. J. Plant Soil. 18: 62-68.

Van Rensburg JBJ, 2007. First report of field resistance by the stem borer, Busseola fusca (Fuller) to Bt-transgenic maize. S. Afr. J. Plant Soil. 24: 147-151.

Van Rensburg GDJ and Bate R, 1987. Preliminary studies on the relative abundance and distribution of the stalk borers Busseola fusca and Chilo partellus. 212: 49-52. Technical Communication, Department of Agriculture and Water Supply, Pretoria, Republic of South Africa.

Van Rensburg JBJ and Van den Berg J, 1992a. 


\section{A. Kotey et al.}

Infestation patterns of the stalk borers Busseola fusca Fuller (Lepidoptera: Noctuidae) and Chilo partellus (Swinhoe) (Lep.: Pyralidae) in grain sorghum. J. Entomol. Soc. South. Afr. 55:197212.

Van Rensburg JBJ and Van den Berg J, 1992b. Timing of insecticide application for stem borer control in maize and grain sorghum. Appl. Plant Sci. 6: 2427.

Van Rensburg JBJ, Van Rensburg G, Giliomee $\mathbf{J}$ and Walters M, 1987a. The influence of rainfall on the seasonal abundance and flight activity of the maize stalk borer, Busseola fusca, in South Africa. S. Afr. J. Plant Soil. 4: 183-187.

Van Rensburg JBJ, Walters MC and Gillomee JH, 1988a. Geographical variation in the seasonal moth flight activity of the maize stalk borer, Busseola fusca (Fuller), in South Africa. S. Afr. J. Plant Soil. 2: 123-126.

Van Rensburg JBJ, Giliomee JH and Walters MC, 1988b. Aspects of injuriousness of the maize stalk borer, Busseola fusca (Fuller) (Lepidoptera: Noctuidae). Bull. Entomol. Res. 78: 101-110.

Visser A, Du Plessis H, Erasmus and Van den Berg J, 2020. Larval migration behaviour of Busseola fusca (Lepidoptera: Noctuidae) on Bt and non-Bt maize under semi-field and field conditions. Insects. 11:16.

\section{Contribution of Authors}

Kotey DA: Experimental design and set-up, data collection, analysis and interpretation and drafting of manuscript

Assefa Y: Conceived the idea and sourced for funding, manuscript review and proof reading Van den Berg J: Sourced for funding, manuscript review and proof reading 